\title{
Using birds to set conservation priorities for Pantanal wetland forests, Brazil
}

\author{
JOÃO BATISTA DE PINHO and MIGUEL ÂNGELO MARINI
}

\section{Summary}

The Pantanal of Brazil, one of the largest wetlands in the world, is suffering severe threats, such as forest and grassland clearance on the surrounding plateau, conversion of forests and savannas for cattle ranching and effects of large development projects. We used richness, abundance and composition of bird species in four forest types to propose conservation priorities for the northern Pantanal. Birds from II sites (a total of 41 points) were sampled through point counts and mistnetting. In total 215 species were recorded in the forests. Two evergreen forest types (cambarazal and landi) had higher estimates of bird richness and abundance than two dry forest types (carvoeiro and cordilheira). The evergreen forests also had more species exclusive to them and were more similar to each other than the dry forests. Selection of forests to be conserved in the northern Pantanal should give priority to evergreen forests and secondarily to dry forests. Cambarazal should be the first forests to be conserved. If the Pantanal inundation cycle is altered by the construction of hydroelectric dams or the Paraguay-Paraná waterway, cambarazal and landi may no longer become flooded, decreasing local species richness. Before our recommendations are considered for conservation and management decisions, more studies on other groups of organisms should also be taken into consideration, and similar studies should be conducted in other regions of the Pantanal. Conservation of Pantanal forest birds depends on a deeper understanding of their use of several habitats, stronger protection of the forests with higher diversity, and public policies that guarantee the long term maintenance of natural flooding cycles.

\section{Introduction}

The Brazilian Pantanal is one of the largest wetlands of the world. It is strongly affected by a cycle of flooding and dry periods and this seasonality promotes a high diversity of habitats and microhabitats (Da Silva et al. 2001). The periodic flooding is associated with poor soils and road access, making it unsuitable for agriculture (Padovani et al. 2004, Nunes da Cunha et al. 2007), but the Pantanal is under severe threat due to conversion of forest and savanna for cattle ranching, large development projects, hunting, invasion of exotic species and pollution (Alho et al. 1988, Padovani et al. 2004, Harris et al. 2005). Forest and grassland clearance of the surrounding plateau creates additional threats. The effects of these threats on wildlife have rarely been assessed, except for a few notable cases (Silva et al. 1998, Da Silva et al. 2001, Bouton and Frederick 2003).

Two of these threats may cause substantial changes to the landscape. Conversion of forests to pasturelands causes the loss of the higher, non-flooded forest habitats that are important during the 3-6 month flooding period (Junk 1996, Tubelis and Tomás 1999) and development projects, such as hydroelectric power plants and the major Paraguay-Paraná waterway (Lorival et al. 1996), will alter natural hydrological patterns and are predicted to cause the loss of large areas of wetland (Hamilton 1999, Harris et al. 2005, 2006).

Forests of the Pantanal can be classified into several types and vary regionally (Nunes da Cunha et al. 2006, Nunes da Cunha and Junk 2009). Forest habitats usually lie above the 
regular inundation level and suffer the most from anthropogenic impacts (Nunes da Cunha et al. 2006). Forests cover $45.3 \%$ of the Pantanal of Poconé landscape, including two types of dry forest (cordilheira and carvoeiro) comprising $12 \%$ and two types of evergreen forest (cambarazal and landi) comprising 6.4\% (Silva et al. 2000, Nunes da Cunha et al. 2007), thus making these forests some of the most threatened habitats.

With 463 species recorded, bird species diversity in the Pantanal is not especially high (Brown Jr. 1986, Mittermeier et al. 1990, Tubelis and Tomás 2003, Marini and Garcia 2005) and there are no endemics and few endangered species compared to other Brazilian biomes. Its central location in South America and its use by migratory birds makes it an important Neotropical conservation area.

Forests are the most threatened habitat in the Pantanal and little is known about the species that occur in them. Even though the region has been visited by several researchers, such as the Roosevelt-Rondon expedition (see Tubelis and Tomas 2003 for a review), extensive areas of the Pantanal remain unexplored. Studies indicate that the structure and dynamics of bird communities are strongly related to spatial heterogeneity in habitats and inundation cycles (Tubelis and Tomas 1999, Marini 2001, Figueira et al. 2006, Signor 2008, Tizianel 2008, Nunes 2009 and Yabe et al. 2010). Loss of forest will alter habitat mosaics and may impact on the bird assemblages that occur in them. In this paper, we studied the richness and abundance of birds in four types of forest of the northern Pantanal. Our results were used to help set conservation priorities for the region in light of the increased rate of forest conversion and the potential impacts of large development projects.

\section{Methods}

\section{Study area}

Bird communities were studied at the "Cuiabá-Bento Gomes-Paraguaizinho" Pantanal, locally called Pantanal of Poconé (Franco and Pinheiro 1982), most specifically at the Pirizal locality ( $\left.16^{\circ} 15^{\prime} 12^{\prime \prime} \mathrm{S}, 56^{\circ} 22^{\prime} 12^{\prime \prime} \mathrm{W}\right)$, Nossa Senhora do Livramento municipality, state of Mato Grosso, Brazil (Figure 1). The climate of the Pantanal is characterised by a dry season from May to September, and a rainy season from October to April (Nunes da Cunha and Junk 2004). Mean annual rainfall from 1999 to 2002 was $1,159 \mathrm{~mm}$, with a maximum in December and minimum in August. Mean low temperature was $20.9^{\circ} \mathrm{C}$ and mean maximum was $32.5^{\circ} \mathrm{C}$. Around $48.5 \%$ of the region is represented by flooded grasslands and marshes, $45.3 \%$ by forests and $6.3 \%$ by other habitats (e.g. water bodies) (Silva et al. 200o).

In the Pantanal, different types of soils and inundation levels are responsible for a high degree of variation in vegetation cover, creating a landscape mosaic (Silva et al. 2000, Nunes da Cunha et al. 2002, Nunes da Cunha and Junk 2009). We studied four forest types, two that undergo inundation (cambarazal and landi) comprising $12 \%$ of the study region, referred to here as "evergreen forests" and two that do not suffer inundations (cordilheira and carvoeiro) comprising $45.3 \%$ of the area and referred to here as "dry forests" (Nascimento and Nunes da Cunha 1989, Nunes da Cunha 1990, Ribeiro 1999, Nunes da Cunha et al. 2006, Nunes da Cunha and Junk 2009). Description of forest types can be found in the online Supplementary Materials.

\section{Sampling methods}

Eleven sampling sites were selected through field evaluation of the vegetation. Three spatial replicates were established for each vegetation type (Table 1 ), except for carvoeiro which had only two patches at the Pirizal locality (Figure 1). Any two sites were separated by at least $250 \mathrm{~m}$ of grassland and any two sites of the same vegetation type were at least $800 \mathrm{~m}$ apart to ensure sampling independence.

Birds from all 11 sites were sampled through point counts and mist-netting. Sample sizes were small, since the Pantanal vegetation is a mosaic of forest and open habitat patches (Table 1; Figure 1), and census points need to be far apart to ensure independence. Censuses, conducted in the morning 


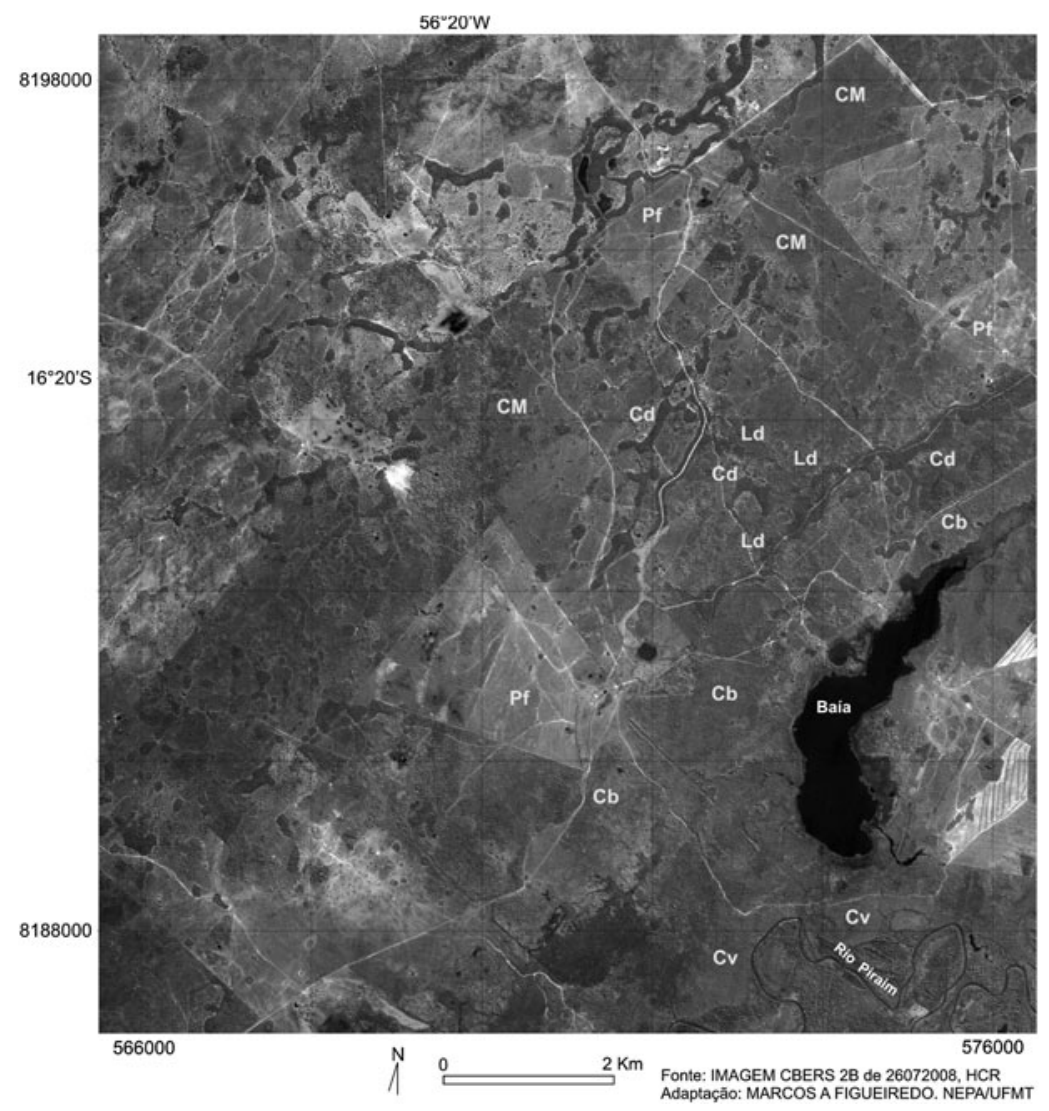

Figure 1. Map of the study site at Pirizal, Pantanal of Poconé, state of Mato Grosso, Brazil. Legends: $\mathrm{Cb}=$ cambarazal; $\mathrm{Ld}=$ landi; $\mathrm{Cd}=$ cordilheira and $\mathrm{Cv}=$ carvoeiro.

Table 1. Sample design for mist-net and point count census: size of areas in hectares (ha), number of nets (NR), number of survey points (NP) and sample effort.

\begin{tabular}{|c|c|c|c|c|c|}
\hline \multirow[t]{2}{*}{ Habitat } & \multirow[t]{2}{*}{ Size (ha) } & \multicolumn{2}{|c|}{ Nets } & \multicolumn{2}{|c|}{ Point count } \\
\hline & & NR & Sample effort & $\mathrm{NP}$ & Sample effort \\
\hline Cambarazal I & 30.2 & 10 & $950 \mathrm{~h}$ & 4 & $560 \mathrm{~min}$ \\
\hline Cambarazal II & 30.5 & 10 & $950 \mathrm{~h}$ & 4 & $560 \mathrm{~min}$ \\
\hline Cambarazal III & 25.6 & 10 & $950 \mathrm{~h}$ & 3 & $410 \mathrm{~min}$ \\
\hline Cordilheira I & 12.1 & 10 & $950 \mathrm{~h}$ & 4 & $560 \mathrm{~min}$ \\
\hline Cordilheira II & 12.4 & 10 & $950 \mathrm{~h}$ & 4 & $560 \mathrm{~min}$ \\
\hline Cordilheira III & 12.3 & 10 & $950 \mathrm{~h}$ & 4 & $560 \mathrm{~min}$ \\
\hline Landi I & 13.2 & 10 & $950 \mathrm{~h}$ & 4 & $560 \mathrm{~min}$ \\
\hline Landi II & 13.1 & 10 & $950 \mathrm{~h}$ & 3 & $410 \mathrm{~min}$ \\
\hline Landi III & 18.4 & 10 & $950 \mathrm{~h}$ & 3 & $410 \mathrm{~min}$ \\
\hline Carvoeiro I & 30.6 & 10 & $950 \mathrm{~h}$ & 4 & $560 \mathrm{~min}$ \\
\hline Carvoeiro II & 25.2 & 10 & $950 \mathrm{~h}$ & 4 & $560 \mathrm{~min}$ \\
\hline
\end{tabular}


between sunrise and oghoo, always started at a different point of the trail (from start to end, from end to start, from middle to start and from middle to end). Censuses were conducted monthly from April to December 2000 and every other month from January to September 2001. It was not possible to conduct censuses from January to March 2000 because of very high flooding in the region. We established four sampling points along a trail in each of the 11 sites, always at least $50 \mathrm{~m}$ from the forest edge, with a total point count sampling effort of $560 \mathrm{~min}$ at each spatial replicate. The only exceptions were one of the cambarazal sites and two landi sites which had only three sampling points and a point count sampling effort of $410 \mathrm{~min}$, due to natural spatial limitations of these habitats.

The point count method was adapted from Vielliard and Silva (1990) and Bibby et al. (1993) to quantify birds. Each of the points, $150 \mathrm{~m}$ from each other, was sampled for 10 minutes/month. During these 10 minutes of sampling, we recorded all birds heard or seen. A digital recorder with a microphone (Sennheiser ME 88 long shotgun) was used to record bird songs. Unknown songs were mostly not recorded during sampling periods, but during the interval between census periods. The census began after one of us (JBP) was trained and able to identify the great majority of bird songs of the region.

The same trails used for the censuses were used for mist-netting and banding. We ran the nets monthly from September 1999 to December 2000, and every other month from March to August 2001, from o6hoo to 11 hoo. We used $12 \mathrm{~m}$ long by $2.7 \mathrm{~m}$ high mist-nets with mesh size of $36 \mathrm{~mm}$. We opened nets in straight lines, one next to the other, from $10 \mathrm{~cm}$ from the ground. One mist-net hour is the equivalent of one $12-\mathrm{m}$ long net open for one hour. Recaptured birds were not considered. Mist-net sampling effort was similar (1o nets and 950 mist-net hours) among all sites.

\section{Analyses}

We conducted analyses with monthly data grouped by season, as defined by the water fluctuation level in the region following (Ribeiro 1999, Nunes da Cunha and Junk 2004): flooded (JanuaryApril), run-off (May-August) and dry (September-December). It is important to stress that what we call "dry season" based on water fluctuation level does not correlate with the "dry climatic season" with low precipitation between May and September. The dry climatic season corresponds mostly with the run-off season. Abundance of each species was calculated using the Index of Point Abundance (IPA) (Aleixo and Vielliard 1995) for the point count data. We calculated the relative capture frequency (number of captures/mist-net hours) for the mist-net data. Taxonomy followed BirdLife International (2009) and CBRO (2009) and conservation status followed IBAMA (2009) and IUCN (2009).

For each forest type, we constructed a species accumulation curve and estimated species richness using the first order non-parametric jackknife estimator, with a $95 \%$ confidence interval, using EstimateS, version 6.o BI (Colwell 2000). For both sampling methods, we estimated values of richness for each spatial replicate of each forest type. We used a two-way ANOVA to compare richness estimates and abundance values (IPA) between habitats and seasons. Finally, we used a Bonferoni test for multiple comparisons of the means. We conducted all statistical analyses using Systat 9.o.

Species composition was analysed with non-metric multidimensional scaling (NMDS) (McCune and Grace 2002). We ordinated bird species community composition with bird abundance (quantitative ordination) and species presence/absence (qualitative ordination) data. The quantitative ordination was used to capture the patterns influenced by the most abundant species and thus show the contribution of the relative abundance of species among forests. We used the BrayCurtis index as a dissimilarity measure (Faith et al. 1987, McCune and Grace 2002) on matrices standardised over sites (relative abundance of each species per site). Abundant species usually represent a small proportion of the total number of species of an animal community. In analyses sensitive to variations in abundance, these few abundant species may represent more than $80 \%$ of the individuals, and therefore have a heavy weight in the process of detection of community structure. However, when the most abundant species are also the most frequent, their contribution to the results in presence/absence analyses is relatively small. For this reason we 
also made community ordinations with the presence/absence data using Sorensen's similarity index (Legendre and Legendre 1998), which, in this case, stress the pattern of the rarest species. Ordinations were run with the PCORD program (McCune and Mefford 1999).

\section{Results}

Using both methods, we recorded 213 species across the four forest types (Appendix $\mathrm{S}_{1}$ ). The sampling effort curves, however, revealed that even after 2,000 or 3,00o hours of mist-netting and more than 18 hours of census in each area, the number of species in each forest type was still increasing. For point counts, cambarazal was the forest type with the highest number of species recorded (Figure 2), and for mist-nets carvoeiro and cordilheira had the lowest species richness (Figure 3).

\section{Species richness estimates}

The evergreen forests (cambarazal and landi) had higher estimates of species richness throughout the year compared with the two dry forests (carvoeiro and cordilheira) (Figures 4 and 5). Significant variation was found in species richness among habitats (point count: $F=16.340, P<$ 0.001; mist-net: $F=17.835, P<0.001$ ), and among seasons (point count: $F=10.066, P=0.001$; mist-net: $F=32.915, P<$ o.001).

\section{A. Cambarazal}

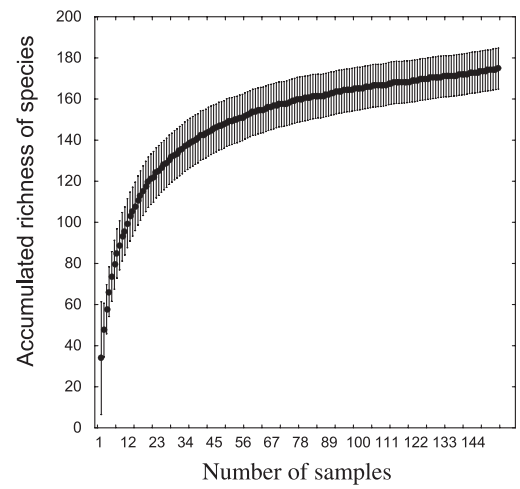

\section{Carvoeiro}

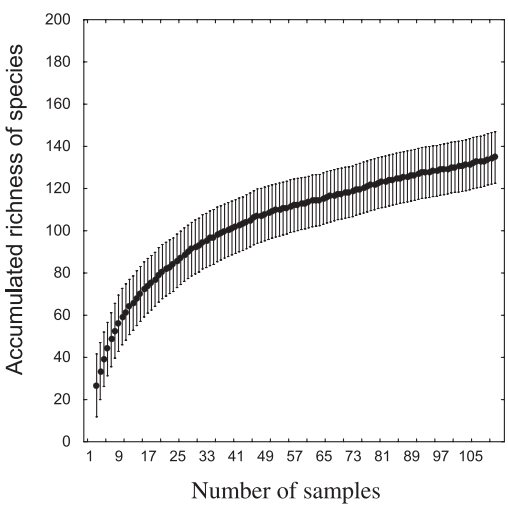

\section{B. Landi}

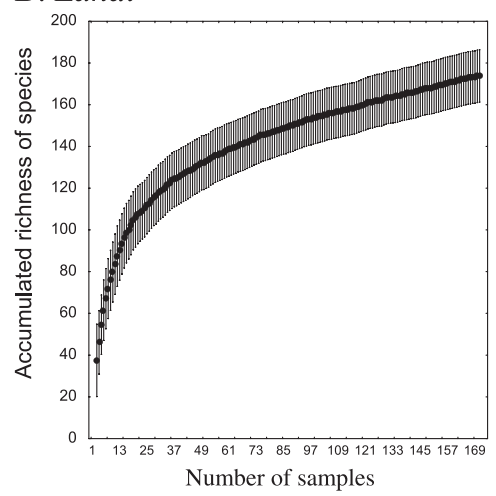

D. Cordilheira

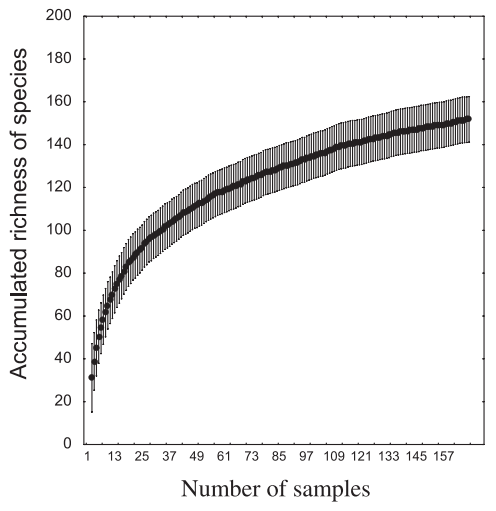

Figure 2. Estimated number of bird species using point count data for four forest types at the Pantanal of Poconé. 
A. Cambarazal

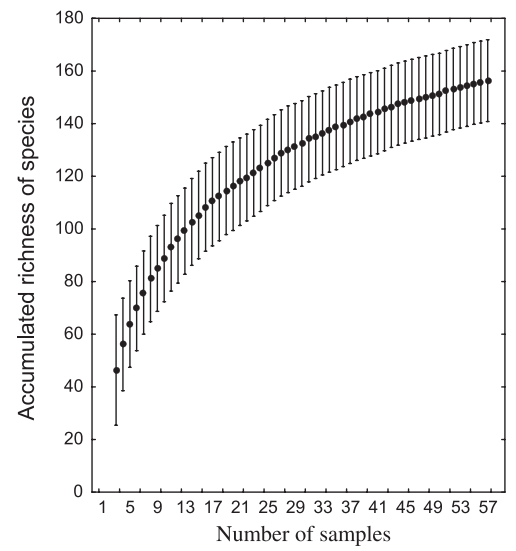

C. Carvoeiro

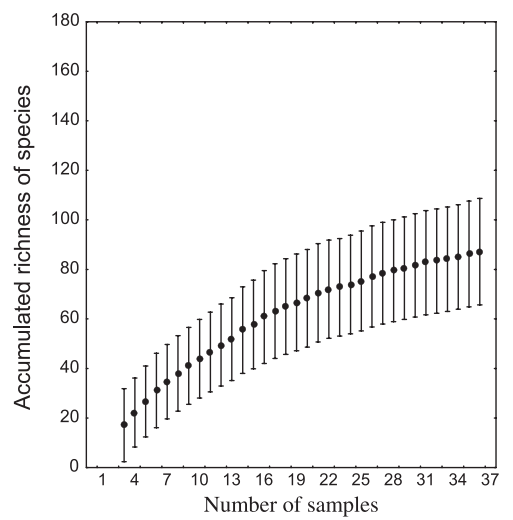

B. Landi

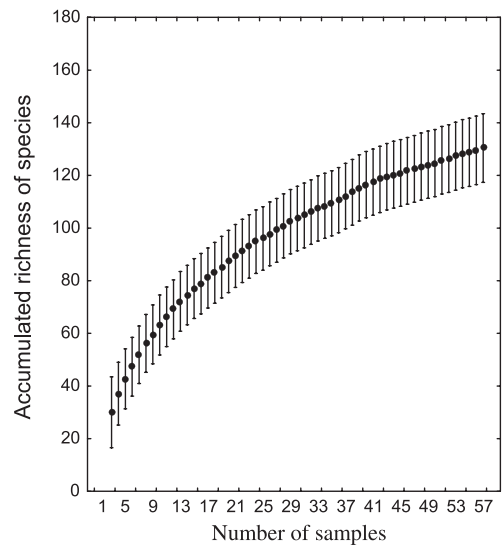

D. Cordilheira

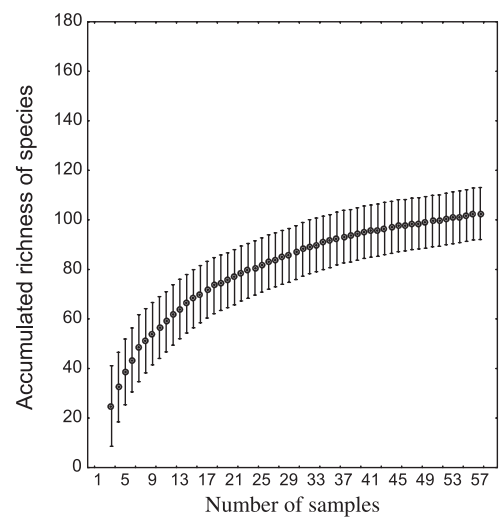

Figure 3. Estimated number of bird species using mist-net data for four forest types at the Pantanal of Poconé.

Pairwise comparisons of species richness for the point count data revealed statistically significant differences among all forests (all $F>5.565$, and $P<0.028$ ), except between landi and carvoeiro $(F=0.516, P=0.480)$ and landi and cordilheira $(F=3.364, P=0.081)$. Similarly, the mist-net data also revealed statistically significant differences between all forests (all $F>$ 15.276, and $P<0.017)$, except between landi and cordilheira $(F=9.866, P=0.185)$.

Estimates of species richness through point counts had the same pattern in the four forest types through the seasons. More species were recorded in dry and run-off seasons compared with the flooded season (Figure 4). The flooded and run-off seasons $(F=17.665, P<0.001)$ and the dry and flooded seasons $(F=11.986, P=0.002)$ differed, but the run-off and dry seasons $(F=0.549$, $P=0.467$ ) were similar. For the mist-net data, all three seasons had the same richness (all $F>$ 9.968, and $P<0.008$ ).

The significant habitat ${ }^{*}$ season interaction for the mist-net data revealed complex variations in species richness, related to variations in species richness of the dry forests during the flooded season. The interaction habitat ${ }^{*}$ season was not significant for the point counts $(F=1.002, P=$ $0.450)$, but was significant for the mist-net data $(F=2.814, P=0.036)$. Carvoeiro had an increase in species richness during the flooded season, while cordilheira had a decrease in species richness during this period (Figures 4 and 5 ). 
A

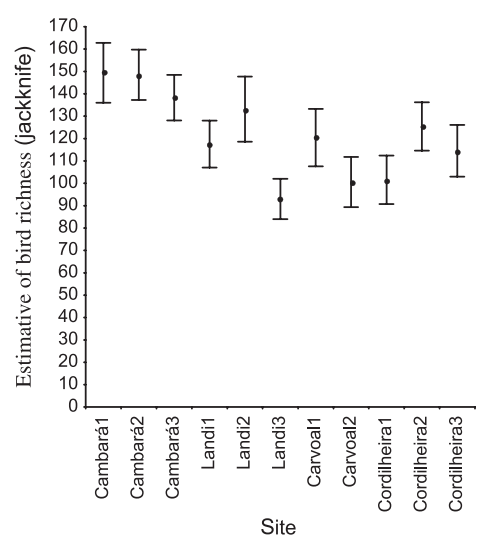

C

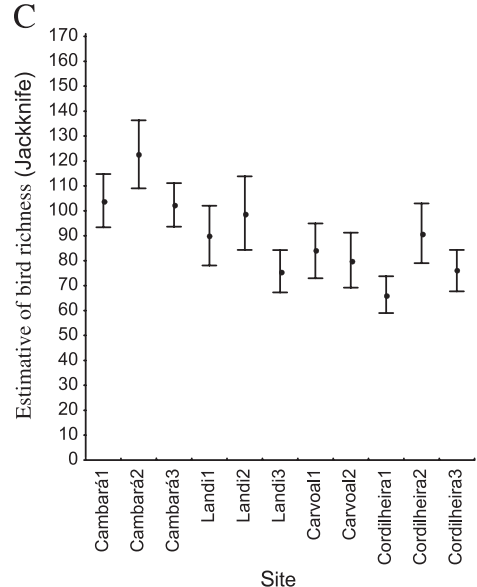

B

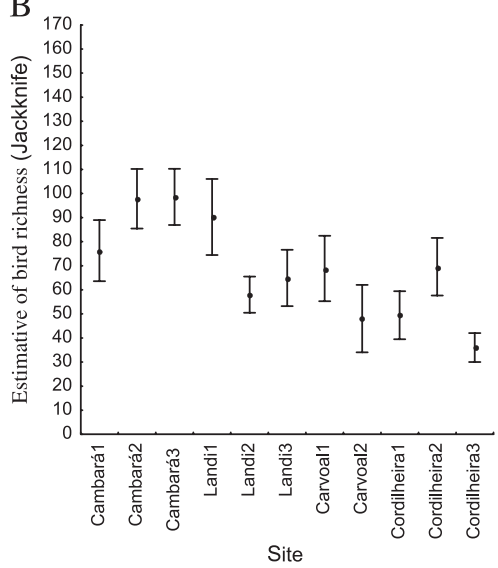

D

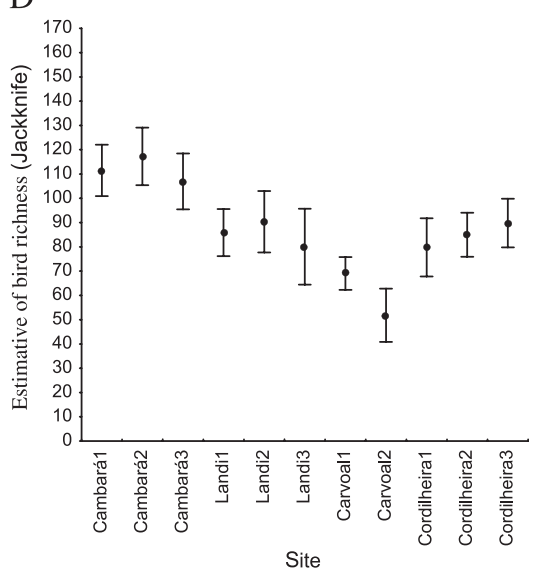

Figure 4. Mean ( $\pm 95 \% \mathrm{CI}$ ) bird species richness estimated through first order Jackknife for point count data at the Pantanal of Poconé. $\mathrm{A}=$ all seasons together; $\mathrm{B}=$ flood season; $\mathrm{C}=$ runoff season; $\mathrm{D}=$ dry season.

\section{Abundance estimates}

Species abundance differed between habitats for both sampling methods, in a similar manner to the species richness results. Significant variation was found in species abundance among habitats (point count: $F=34.869, P<0.001$; mist-net: $F=24.026, P<0.001$ ), and among seasons (mistnet: $F=28.311, P<0.001$ ), but there was no seasonal effect (point count: $F=1.218, P=0.316$ ). Evergreen forests had higher abundance estimates than dry forests in most cases; cambarazal had the highest values, followed by landi, cordilheira, and lastly carvoeiro. Pairwise comparisons of species abundance for the point count data differed between most forest types (all $F>4.600$, all $P<0.044)$, except between cordilheira and carvoeiro $(F=0.056, P=0.816)$. For the mist-net data, the results were very similar, with all differences in abundance between forests significant (all $F>7.123$, all $P<0.014$ ), except for the difference between landi and cordilheira $(F=0.666$, $P=0.423)$.

Abundance for the mist-net data differed among the three seasons (all $F>11.074$, all $P<0.003$ ). There were no differences, however, among seasons for the point count data. There was no 

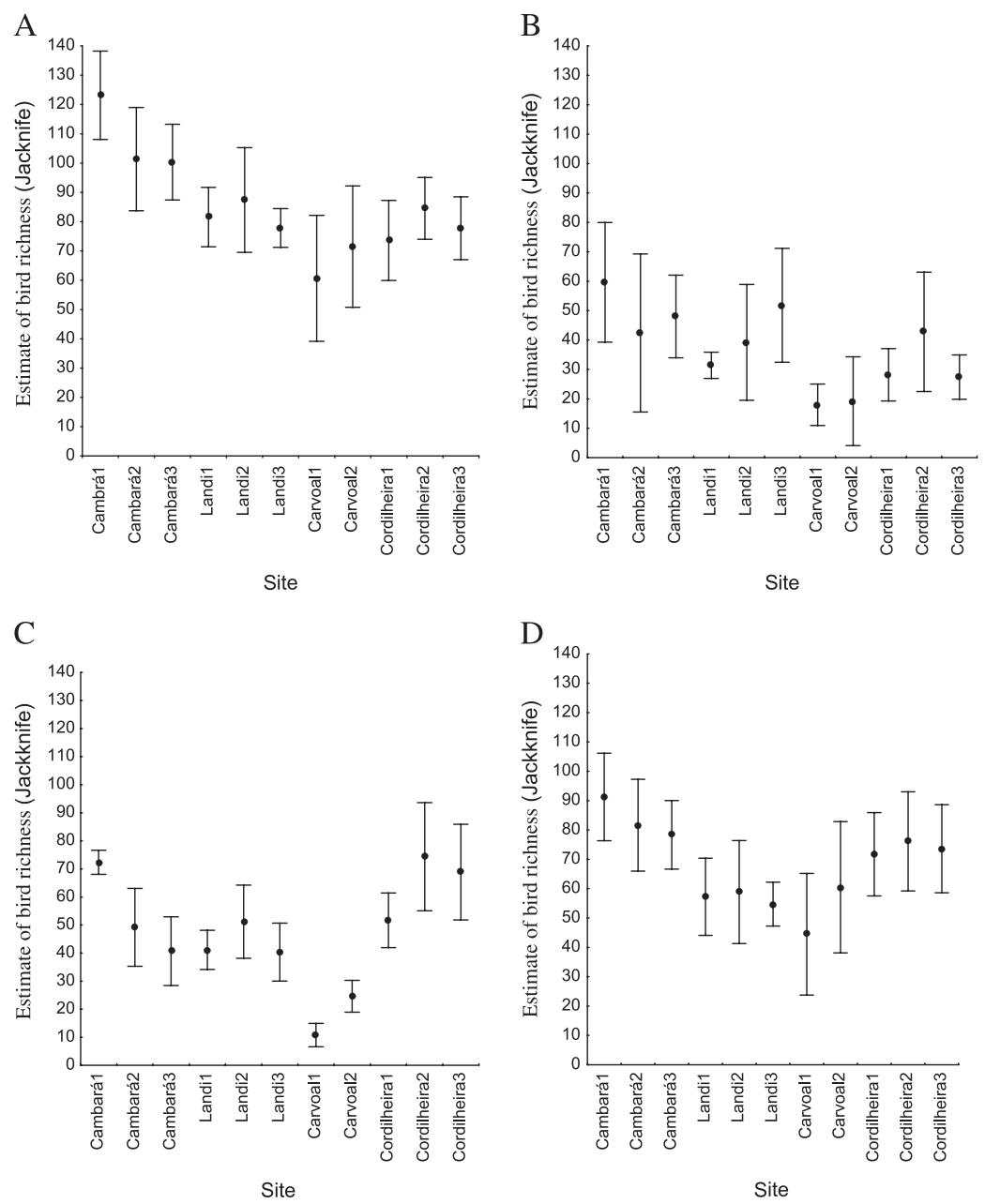

Figure 5. Mean ( $\pm 95 \% \mathrm{CI}$ ) bird species richness estimated through first order Jackknife for mist-net data at the Pantanal of Poconé. $\mathrm{A}=$ all seasons together; $\mathrm{B}=$ flood season; $\mathrm{C}=$ run-off season; $\mathrm{D}=$ dry season.

significant interaction between habitat ${ }^{*}$ season for either method $(F=1.002, P=0.450$ and mistnet $2.814, P=0.036)$.

\section{Similarity comparisons}

Birds used the four forests in distinct ways. Of the 215 bird species recorded, 128 (59.5\%) used three or four forest types, 54 (25\%) used only two forest types and 33 (15\%) used only one forest type. The two evergreen forests had almost five times more species exclusive to them $(n=46$; cambarazal $=17$ species; landi $=8$ species; both $=21$ species $)$ than the two dry forests $(n=10$; cordilheira $=5$ species; carvoeiro $=3$ species; both $=2$ species) (Appendix SI).

The two-dimension bird community ordination by NMDS captured $89.9 \%$ of the variation in the original distances for the quantitative data (Figure 6A) and $86.8 \%$ for the qualitative data 

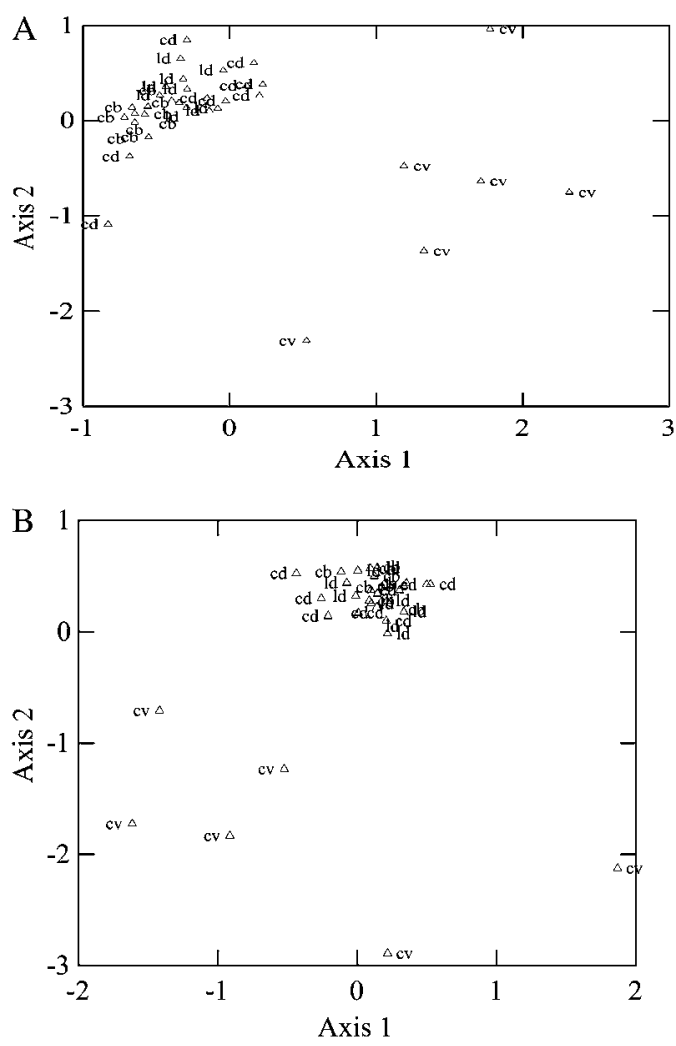

Figure 6. Ordination of bird species composition of the Pantanal of Poconé by non-metric multidimensional scaling (nMDS). $\mathrm{A}=$ with bird abundance (quantitative ordination) data; $\mathrm{B}=$ with species presence/absence (qualitative ordination) (B) data. $\mathrm{cb}=$ cambarazal; $\mathrm{ld}=$ landi; $\mathrm{cd}=$ cordilheira and $\mathrm{cv}=$ carvoeiro.

(Figure 6B). Similarity indexes varied little among the four forest types, but carvoeiro differed most from the other three forests. The two evergreen forests were more similar to each other than any other forest pair.

\section{Species composition}

Of the 213 species recorded, 185 occurred in cambarazal, 113 in landi, 145 in cordilheira and 111 in carvoeiro. Three or four forest types were used by 127 (60\%) species, two forest types by 54 $(25.5 \%)$ species and 31 (14.5\%) species occurred in only one forest type. The most frequent species in all forest types, and species exclusive to each type, are listed in Appendix S2.

\section{Discussion}

\section{Species richness and abundance estimates}

Our finding that evergreen forests had higher richness and abundance of birds than dry forests supports the pattern found in other sites (Hespenheide 1980, Tellería and Santos 1993). Evergreen forests have greater habitat heterogeneity than non-flooded forests (Ribeiro 1999, Nunes da 
Cunha and Junk 2004). This structurally more complex vegetation type decreases the effects of seasonality, resulting in higher stability in resource availability and hosting more year-long residents (Karr 1976, Hurlbert and Haskell 2003). Evergreen forests are also probably more resistant to seasonal changes in water availability, since during the dry season the forests are at the inundation run-off stage and have moist soils.

Floristic diversity is apparently not correlated with bird diversity in the forests of our study site. Although we did not measure floristic diversity in this study, previous work indicates that there are differences between forest types (Nunes da Cunha and Junk 1996). Cordilheira is associated with high floristic diversity but this study showed low bird species diversity. Carvoeiro, a forest type with low floristic diversity (Pinheiro 2001), supported the lowest abundance and richness of birds. Its low spatial heterogeneity probably provides limited sites for bird reproduction, shelter or feeding. Carvoeiro forests, however, represent an important food source for Psittacidae, which feed on oil-rich seeds of Callistene fasciculata mostly during the run-off season (May-August) (J. Pinho pers. obs.).

\section{Do the dry forests act as a refuge during the inundation season?}

The dry forests did not host more species during the flooded season, contrary to the hypothesis that birds would use the higher, dry areas at this time. Both cordilheira and carvoeiro retained low richness and abundance when compared to the other seasons. Cordilheira does not act as a refuge for animals/birds during the dry climatic (run-off) season, as has been suggested by Junk (1996), Nunes da Cunha and Junk (1996) and Tubelis and Tomás (1999). In fact, the cordilheira had the lowest abundance values of all four forest types during this season (Figures 4 and 5). Seasonal variations in species richness and abundance were more evident in the dry forests than in the evergreen forests. Evergreen forests were almost always more diverse and had more individuals than non-flooded ones. There was a decrease of at least $25 \%$ in abundance during the flooded season compared to the run-off and dry seasons in the four forests altogether (Appendix $\mathrm{S}_{3}$ ). The flooded season is the one with lowest richness in cambarazal and landi, according to both sampling methods, probably due to the flooding of their understorey. The decrease in richness and abundance of birds in forests of the region during the flooded season might be explained by the migration of some species from the Pantanal lowlands, perhaps to areas on the surrounding plateau (authors' pers. obs.). Also, the higher richness and abundance of species in the forests during the run-off and dry seasons, compared to the flooded season, might be explained by greater availability of non-flooded habitat due to the higher, non-flooded understorey), and higher insect (Marques et al. 2001) and fruit (Nunes da Cunha and Junk 1996) availability.

\section{Similarity comparisons}

The similarity indices varied little among three of the four types of forest, not adding much to the evaluation of the importance of each forest type for conservation. However, they reinforce the fact that carvoeiro is less similar to the other three types of forest, probably due to its lower richness. The two evergreen forests had the highest similarity indices, probably due to their structural similarities. The greatest similarity, between cambarazal and landi, may be related to the similarity of their vegetation structure, their similar offer of resources to birds or their closest spatial proximity in the landscape. The highest similarity between carvoeiro and cordilheira may also be related to their vegetation type, similar vegetation structure, and the lack of flooding.

\section{Conservation applications}

Approximately $95 \%$ of the region's forest avifauna is represented in evergreen forests alone. The two evergreen forest types had nearly five times more exclusive species than the dry 
forests (Appendix $\mathrm{S}_{3}$ ). Also, none of the 1o species exclusive to the dry forests are of conservation concern, since some are rare in these forests (Red-throated Piping Guan Aburria cujubi, Black-and-white Hawk-eagle Spizaetus melanoleucus, White-chinned Sapphire Hylocharis cyanus and Chotoy Spinetail Schoeniophylax phryganophilus), some do not depend on these forests for survival in the region (Red-throated Piping Guan, Black-andwhite Hawk-eagle and Chopi Blackbird Gnorimopsar chopi), and one is an abundant habitat generalist (Chopi Blackbird). The five species exclusive to the cordilheira (White-faced Whistling-Duck Dendrocygna viduata, Pearl Kite Gampsonyx swainsonii, Smooth-billed Ani Crotophaga ani, Ochre-cheeked Spinetail Synallaxis scutata and Sepia-capped Flycatcher Leptopogon amaurocephalus) have large geographical ranges or occur in other non-forested habitats. We must stress that gallery forests, not studied here, also host a high number of species (Cintra and Yamashita 1990, Figueira et al. 2006), but represent only $2.4 \%$ of the Pantanal (Silva et al. 2000).

Based on the richness, abundance and species composition, priority efforts should be dedicated first to the evergreen forests and second to the dry forests. Cambarazal should be the first forest type to be conserved, since it harbours the highest species richness of birds throughout the year. Cordilheira is already preferred for conversion into pasturelands in the interior of the Pantanal (Silva et al. 1998). Gallery forests should always be conserved, not only because of their high diversity (Cintra and Yamashita 1990, Figueira et al. 2006), but because they protect watersheds, and are already partially protected by Brazilian laws.

More studies on other groups of organisms should be taken into consideration before our recommendations are considered for conservation planning and management decisions. For example, studies reveal that cordilheira has high floristic diversity, compared with the carvoeiro (Nunes da Cunha and Arieira 1996, Nunes da Cunha et al. 2002). Contrary to our study, the richness and abundance of marsupials were much higher in landi than in cambarazal, but cordilheira had similar marsupial abundance to, but lower richness than, cambarazal (Aragona and Marinho-Filho 2009). The occurrence of endangered and endemic species should also be taken into consideration. The Pantanal, however, supports no endemic birds and only 13 birds are threatened (Tubelis and Tomás 2003, Marini and Garcia 2005). We recorded only two threatened species (Chestnut-bellied Guan Penelope ochrogaster and Hyacinth Macaw Anodorhynchus hyacinthinus) in our study area (Appendix S1). Another aspect that should be evaluated is the relative importance of other non-flooded habitats, especially the more open savanna (cerrado) and other monospecific stands, for the maintenance of bird diversity in the Pantanal wetlands.

Development projects in the Pantanal will alter natural hydrological patterns and flooding models predict the loss of large wetland areas (Hamilton 1999). If the inundation regime is altered by the construction of hydroelectric power plants or the Paraguay-Paraná waterway, cambarazal and landi may no longer become flooded, and two of the most important forest types for birds of the northern Pantanal might have their structure altered or even disappear. As a result, dozens of bird species that rely heavily on these forests for survival in the region might become locally threatened. For example, White-lored Spinetail Synallaxis albilora, Mato Grosso Antbird Cercomacra melanaria, Buff-breasted Wren Cantorchilus leucotis and Band-tailed Antbird Hypocnemoides maculicauda were mostly associated with, and abundant in, forests close to water bodies. The first two species in particular have a large part of their distribution in the Pantanal lowland (del Hoyo et al. 2003). The same might apply to some migratory species (Antas 1994).

\section{Supplementary Material}

The supplementary materials for this article can be found at journals.cambridge.org/bci. 


\section{Acknowledgements}

This is a contribution of the Nucleus of Ecological Researches of the Pantanal (NEPA). This study was supported by grants from Pantanal Research Center (CPP), Instituto Nacional de Ciëncias e Tecnologia em Áreas Úmidas (INAU), and the Ministério de Ciência e Tecnologia (MCT). This study was supported by a fellowship from the Coordenação de Aperfeiçoamento de Pessoal de Nível Superior (CAPES) and a grant CNPq. The graduate programme of "Conservação e Manejo da Vida Silvestre" from UFMG and the US Fish and Wildlife Service provided support. MÂM was supported by a Researcher Fellowship from CNPq. We thank M. Aragona, A. Chiarello, J. E. Figueira, A. Hass, J. M. Penha, M. Rodrigues and an anonymous reviewer for criticisms of earlier drafts of the manuscript.

\section{References}

Aleixo, A. and Vielliard, J. M. E. (1995) Composição e dinâmica da avifauna da mata de Santa Genebra, Campinas, São Paulo, Brasil. Rev. Bras. Zool. 12: 493-511.

Alho, C. J. R., Lacher Jr.,T. E. and Gonçalves, H. C. (1988) Environmental degradation in the Pantanal ecosystem. BioScience 38 : 164-171.

Antas, P. T. Z. (1994) Migration and other movements among the lower Paraná River valley wetlands, Argentina, and the south Brazil/Pantanal wetlands. Bird Conserv. Int. 4: 181-190.

Aragona, M. and Marinho-Filho, J. (2009) História natural e biologia reprodutiva de marsupiais no Pantanal, Mato Grosso, Brasil. Rev. Bras. Zool. 26: 220-230.

Bibby, C. J., Burgess, N. D. and Hill, D. A. (1993) Bird census techniques. London: Academic Press.

BirdLife International (2009) The BirdLife checklist of the birds of the world, with conservation status and taxonomic sources. Version 2. http://www.birdlife. org/datazone/species/downloads/BirdLife_ Checklist_Version_2.zip [.xls zipped I $\mathrm{MB}$.

Bouton, S. N. and Frederick, P. C. (2003) Stakeholders' perceptions of a wading bird colony as a community resource in the Brazilian Pantanal. Conserv. Biol. 17: 297306.

Brown Jr., K. S. (1986) Zoogeografia da região do Pantanal Mato-grossense. Pp. ${ }^{137-178}$ in EMBRAPA, ed. Anais do $1^{\circ}$ Simpósio sobre recursos naturais e sócioeconômicos do Pantanal. Corumbá: EMBRAPA - CPAP.
CBRO (2009) Checklist of the birds of Brazil. Comitê Brasileiro de Registros Ornitológicos. http://www.cbro.org.br.

Cintra, R. and Yamashita, C. (1990) Habitats, abundância e ocorrência das espécies de aves do Pantanal de Poconé, Mato Grosso, Brasil. Pap. Avul. Zool. 37: 1-21.

Colwell, R. K. (200o) EstimatS: statistical estimation of species richness and shared species from samples. Version 6.ob1. University of Connecticut: http:/viceroy. eeb.uccon.edu/estimates.

Corsini, E. and Guarin Neto, G. (200o) Aspectos ecológicos da vegetação de "Carvoal (Callistene fasciculata (Spr.) Mart.) no Pantanal Mato-Grossense. Pp. 1-52 in M. Dantas, E. K. Resende and J. A. Comastri Filho, eds. Anais do III simpósio sobre recursos naturais e sócioeconômicos do Pantanal - Os desafios do novo milênio, Corumbá: EMBRAPA.

Da Silva, C. J., Wantzen, K. M., Nunes da Cunha, C. and Machado, F. A. (2001) Biodiversity in the Pantanal wetland, Brazil. Pp. $187-215$ in B. Gopal, W. J. Junk, and J. A. Davis, eds. Biodiversity in wetlands: assessment, function and conservation. Leiden, The Netherlands: Backhuys Publishers.

del Hoyo, J., Elliott, A. and Sargatal, J. (2003) Handbook of the birds of the world Broadbills to tapaculos. Barcelona: Lynx Edicions.

Faith, D. P., Minchin, P. R. and Belbin, L. (1987) Compositional dissimilarity as a robust measure of ecological distance. Vegetatio 69: 57-68. 
Figueira, J. E. C., Cintra, R., Viana, L. R. and Yamashita, C. (2006) Spatial and temporal patterns of bird species diversity in the Pantanal of Mato Grosso, Brazil: implications for conservation. Braz. J. Biol. 66: 393-404.

Franco, M. S. S. and Pinheiro, R. (1982) Geomorfologia. Levantamento de recursos naturais, Folhas SE.20 e SE.21, v.27. Pp. 161224 in Projeto RADAMBRASIL. Rio de Janeiro: Ministério das Minas e Energia.

Haase, R. (1999) Litterfall and nutrient return in seasonally flooded and non-flooded forest of the Pantanal, Mato Grosso, Brazil. For. Ecol. Manage. 117: 129-147.

Hamilton, S. K. (1999) Potential effects of a major navigation project (ParaguayParaná hidrovia) on inundation in the Pantanal floodplains. Regulated rivers: Res. Manag. 15: 289-299.

Harris, M. B., Arcângelo, C., Pinto, E. C. T., Camargo, G., Ramos Neto, M. B. and Silva, S. M. (2006) Estimativa da perda de cobertura vegetal original na Bacia do Alto Paraguai e Pantanal brasileiro: Ameaças e perspectivas. Nat. Conserv. 4: 50-66.

Harris, M. B., Tomás, W. M., Mourão, G., Da Silva, C. J., Guimarães, E., Sonoda, F. and Fachim, E. (2005) Safeguarding the Pantanal wetlands: Threats and conservation initiatives. Conserv. Biol. 19: 714-720.

Hespenheide, H. A. (1980) Bird community structure in two Panama forest: residents, migrants, and seasonality during the nonbreeding season. Washington, DC: Smithsonian Institution Press.

Hurlbert, A. H. and Haskell, J. P. (2003) The effect of energy and seasonality on avian species richness and community composition. Am. Nat. 161: 83-97.

IBAMA (2009) Lista oficial de espécies da fauna brasileira ameaçada de extinção. Portaria no. 1522-Anexo à instrução normativa $n$. 3, de 27 de maio de 2003. Brasília: Instituto Brasileiro do Meio Ambiente e dos Recursos Naturais Renováveis (IBAMA), Ministério do Meio Ambiente.

IUCN (2009) 2009 IUCN Red List of threatened species. http://www.iucnredlist.org.

Junk, W. J. (1996) O conceito do pulso de inundação e suas implicações para o Pantanal de Mato Grosso. Pp. ${ }^{17-28}$ in
M. Dantas, J. B. Catto, and E. K. Resende, eds. Anais do II simpósio sobre recursos naturais e sócio-econômicos do Pantanal manejo e conservação. Corumbá: EMBRAPA.

Karr, J. R. (1976) Seasonality, resource availability, and community diversity in tropical bird communities. Am. Nat. 110: 973-994.

Legendre, P. and Legendre, L. (1998) Numerical ecology. Amsterdam, The Netherlands: Elsevier.

Lorival, R. F. F., Da Silva, C. J., Calheiros, D. F., Albuquerque, L. B., Bezerra, M. A. O., Boock, A., Borges, L. M. R., Boulhosa, R. L. P., Campos, Z., Catella, A. C., Damasceno Jr, G. A., Hardoim, E. L., Hamilton, S. K., Machado, F. A., Mourão, G., Nascimento, F. L., Nogueira, F. M. B., Oliveira, M. D., Pott, A., Silva, M. C., Pinto Silva, V., Strüssmann, C., Takeda, A. M. and Tomás, W. M. (1996) Os impactos da hidrovia Paraguai - Paraná sobre a biodiversidade do Pantanal - uma discussão multidisciplinar. Pp. 517-535 in M. Dantas, J. B. Catto, and E. K. Resende, eds. Anais do II simpósio sobre recursos naturais e sócioeconômicos do Pantanal - manejo e conservação. Corumbá: EMBRAPA.

Marini, M. A. (2001) Effects of forest fragmentation on birds of the Cerrado region, Brazil Bird Conserv. Int. 11: 13-25.

Marini, M. Â., and Garcia, F. I. (2005) Bird conservation in Brazil. Conserv. Biol. 19: 665-671.

Marques, M. I., Adis, J., Santos, G. B. and Battirola, L. D. (1996) Terrestrial arthropods from tree canopies in the Pantanal of Mato Grosso, Brazil. Rev. Bras. Entomol. 50:257-267.

Marques, M. I., Adis, J., Nunes da Cunha, C. and Santos, G. B. (2001) Arthropod biodiversity in the canopy of Vochysia divergens (Vochysiaceae), a forest dominant in the Brazilian Pantanal. Stud. Neotrop. Faun. Environ. 36: 205-210.

McCune, B. and Grace, J. B. (2002) Analysis of ecological communities. Gleneden Brach, USA: MjM Software Design.

McCune, B. and Mefford, M. J. (1999) PC-ORD. Multivariate analysis of ecological data. Gleneden Brach, USA: MjM Software Design. 
Mittermeier, R. A., Câmara, I. G., Pádua, M. T. J. and Blanck, J. (1990) Conservation in the Pantanal of Brazil. Oryx 24: 103-112.

Nascimento, M. T. and Nunes da Cunha, C. (1989) Estrutura e composição florística de um cambarazal no Pantanal de Poconé MT. Acta Bot. Brasil. 3: 3-23.

Nunes, A. P. (2009) Ocupação de manchas florestais por três espécies de aves insetívoras do sub-bosque do Pantanal de Nhecolândia, Corumbá - MS. MSc Thesis, Universidade Federal de Mato Grosso do Sul, Campo Grande, Brasil.

Nunes da Cunha, C. (1990) Estudo florístico e fitossociológico das principais formações arbóreas do Pantanal de Poconé, MT. MSc Thesis, UNICAMP, Campinas, Brasil.

Nunes da Cunha, C. and Arieira, J. (1996) Fitossociologia de uma floresta inundável monodominante de Vochysia divergens Pohl (Vochysiaceae), no Pantanal Norte, MT, Brasil. Acta Bot. Brasil. 20: 569-580.

Nunes da Cunha, C. and Junk, W. J. (1996) Composição florística de capões e cordilheiras: localização das espécies lenhosas quanto ao gradiente de inundação no Pantanal de Poconé, MT - Brasil. Pp. 387-405 in M. Dantas, J. B. Catto, and E. K. Resende, eds. Anais do II simpósio sobre recursos naturais e sócio-econômicos do Pantanal manejo e conservação. Corumbá: EMBRAPA.

Nunes da Cunha, C. and Junk, W. J. (2004) Year-to-year changes in water level drive the invasion of Vochysia divergens in Pantanal grasslands. Appl. Veg. Sci. 7: 103-110.

Nunes da Cunha, C. and Junk, W. J. (2009) Landscape units of the Pantanal: structure, function, and human use. Pp. 127-141 in W. J. Junk, C. J. Da Silva, C. Nenes da Cunha and K. M. Wantzen, eds. The Pantanal: Ecology, biodiversity and sustainable management of a large Neotropical seasonal wetland. Sofia, Bulgaria: Pensoft Publishers.

Nunes da Cunha, C., Junk, W. J. and LeitãoFilho, H. F. (2007) Woody vegetation in the Pantanal of Mato Grosso, Brazil: a preliminary typology. Amazoniana XIX: 159-184.

Nunes da Cunha, C., Junk, W. J. and Silveira, E. A. (2002) A importância da diversidade de paisagem e da diversidade arbórea para a conservação do pantanal. Recife: Imprensa Universitária - Universidade Federal de Pernambuco.

Nunes da Cunha, C., Rawiel, P., Wantzen, K. M., Junk, W. J. and Prado, A. L. (2006) Mapping and characterization of vegetation units by means of Landsat imagery and management recommendations for the Pantanal of Mato Grosso (Brazil), north of Poconé. Amazoniana XIX: 1-3.

Padovani, C. R., Cruz, M. L. L. and Padovani, S. L. A. G. (2004) Desmatamento do Pantanal Brasileiro para o ano 2000. IV Simpósio sobre recursos naturais e sócio econômicos do Pantanal. EMBRAPA: http://www.cpap.embrapa.br/agencia/ desmatamento/desmatamento.htm.

Pinheiro, J. (2001) Atributos fitossociológicos de três cerradões de carvoeiros no Pantanal de Poconé. MSc Thesis, Universidade Federal de Mato Grosso, Cuiabá, Brasil.

Ribeiro, G. L. S. (1999) Landi da Moranga: Uma análise da comunidade arbustivoarbórea e sua interface com o campo de murunduns no Pantanal de Poconé - MT. MSc Thesis, Universidade Federal de Mato Grosso, Cuiabá, Brasil.

Signor, C. A. (2008) Padrões espaciais de diversidade de aves em um mosaico de vegetação no Pantanal de Poconé - MT. MS. MSc Thesis, Universidade Federal de Mato Grosso, Cuiabá, Brasil.

Silva, J. M. C. (1995) Birds of the Cerrado region, South America. Steenstrupia 21: 69-92.

Silva, J. S. V., Abdon, M. M., Silva, M. P. and Romero, H. R. (1998) Levantamento do desmatamento no Pantanal Brasileiro até 1990/91. Pesq. Agropec. Brasil. 33: 17391745.

Silva, M. P., Mauro, R., Mourão, G. and Coutinho, M. (2000) Distribuição e quantificação de classes de vegetação do Pantanal através de levantamento aéreo. Rev. Brasil. Bot. 23: 143-152.

Tellería, J. L. and Santos, T. (1993) Distributional patterns of insectivorous passerines in the Iberian forests: does abundance decrease near border? J. Biogeog. 20: 235-240.

Tizianel, F. A. T. (2008) Efeito da complexidade da vegetação de fitofisionomias naturais e pastagens cultivadas sobre 
a comunidade de aves em duas fazendas no Pantanal da Nhecolândia, Corumbá, MTS. MS. MSc Thesis, Universidade Federal de Mato Grosso do Sul, Campo Grande, Brasil. Tubelis, D. P. and Tomás, W. M. (1999) Distribution of birds in a naturally patchy forest environment in the Pantanal wetland, Brazil. Ararajuba 7: 81-89.

Tubelis, D. P. and Tomás, W. M. (2003) Bird species of the Pantanal wetland, Brazil. Ararajuba 11: 5-37.
Vielliard, J. M. E. and Silva, W. R. (1990) Nova metodologia de levantamento quantitativo da avifauna e primeiros resultados no interior de São Paulo, Brasil. Pp. 117-151 in S. M. Azevedo Jr., ed., Anais do IV encontro nacional de anilhadores de aves. Recife: Universidade Federal Rural de Pernambuco. Yabe, R. S., Marques, E. J. and Marini, M. Â. (2010) Movements of birds among natural vegetation patches in the Pantanal, Brazil. Bird Conserv. Int. 20: 400-409.

\section{JOÃO BATISTA DE PINHO*}

Programa de Pós-graduação em Ecologia, Conservação e Manejo da Vida Silvestre, Universidade Federal de Minas Gerais, 31270-910, Belo Horizonte, MG, Brazil.

Núcleo de Pesquisas Ecológicas do Pantanal (NEPA), Instituto de Biociências, Universidade Federal de Mato Grosso, 78060-9oo, Cuiabá, MT, Brazil.

\section{MIGUEL ÂNGELO MARINI}

Departamento de Zoologia, IB, Universidade de Brasília, 70910-90o, Brasília, DF, Brazil.

*Author for correspondence; e-mail: pinho@cpd.ufmt.br

Received 20 March 2010; revision accepted 10 April 2011;

Published online 26 September 2011 